\title{
Applied Error Analysis of Written Production of English Essays of Tenth Grade Students in Ajloun Schools,
} Jordan

\author{
Dr. Firas Ali Suleiman Zawahreh \\ Directorate of Education of Ajloun, Prince Hamzeh Bin Al-Hussien Basic School for Boys \\ Ajloun, Jordan \\ Mobile: 00962795874178; Email: Zawahrehfiras@yahoo.com
}

Accepted: April 6, 2012 Published: April 21, 2012

Doi:10.5296/ijld.v2i2.1680 URL: http://dx.doi.org/10.5296/ijld.v2i2.1680

\begin{abstract}
The objective of this study was investigating the written English errors of tenth grade students in females and males schools in Ajloun, Jordan. It was conducted on purpose of identifying the written errors of English committed by the tenth grade, estimating the predominant errors and the least ones and explaining the causes of the written errors of English committed by the tenth grade students The sample of study consisted of 350 students selected randomly from group of schools in Ajloun. The students were asked to write a free essay about " A journey to the ancient city of Jerash in Jordan" in an ordinary English language exercise in the class. Then the essays collected and analyzed depending on a table of errors adopted from a Ph.D. of ( wakkad,1980). The findings were: First, the most predominant errors among tenth grade students in Ajloun schools within morphology were errors of lack of agreement between subject and the main verb. Second, the most predominant errors among tenth grade students in Ajloun schools within function words were errors of insertion of prepositions. Third, the most predominant errors among tenth grade students within syntax were errors of omission of the main verb. Fourth, the most predominant errors among tenth grade students within tenses were errors of using present instead of past. Fifth, the most predominant errors among tenth grade students within lexical items were errors of lexical items wrongly used in place of others.
\end{abstract}

Keywords: Error Analysis, English Essays, Grammatical errors 


\section{Introduction}

"Errors, like straws, upon the surface flow; he who
would search for pearls must dive below."

\section{John Dryden}

It is not easy for anybody to deny that English is one of the most important languages in the world. It is seen by large number of people as the language of art, science, politics and economics. So when one wants to cope with what happens in the world he must learn English language and that made the ultimate aim of teaching English in Jordan is to enable students to communicate with the speakers of English using both the oral and the written English language.

Languages are of four Skills. English language is not an exception. It consists of four skills: listening, speaking, reading and writing. Brown (2000) explained that in order to master the English language, learners have to be exposed to all of the four basic skills. When students try to practice the last one which is writing they face many difficulties. In fact, writing is the skill in which students produce sentences which are put in a particular order and linked together in certain ways. But still, essays production is the most difficult tiring task.

Raimes (1983) explained that writing is an area in which students commit errors and it is helpful in students' learning because of the following reasons:

" First, it reinforces the grammatical structures, idioms and vocabulary that have been taught to students. Second, when students write, They also have a chance to be adventurous with the language. Third, When they write they necessarily become very involved with the new language, The effect to express ideas, and the constant use of eye. hand and brain is a unique way to reinforce learning. "

There is a kind of agreement that errors are significant in three different ways: " First, they tell the teacher when he undertakes a systematic analysis how far toward the goals the learner have progressed and what remains for him to learn. Second, they give researchers evidences of how language is learned and what strategies and procedures the learners are employing in their discovery of the language. Third, they are unavoidable to the learner himself, because we can consider the process of making of errors as a devise the learner uses in order to learn. In other words, It is a way of testing the learners' hypotheses about the nature of the language they are learning.

Error analysis ( EA) became a preferred tool of studying second language analysis. It is seen as one of the best types of linguistic studies that focuses on the learners' errors. It consists of a comparison between the errors made in target language and within that TL itself.

Corder (1967) who is considered the father of EA contended that those errors are "important in and of themselves". So it can be said that errors made by language learners make it possible to determine areas that need reinforcement in teaching. He added that EA has two objects: One theoretical and another applied. The theoretical object is to understand what and how a learner learns when he studies an L2. The applied object is to enable the learner to learn more efficiently by using the knowledge of his dialect for pedagogical purposes. At the same time, the investigation of errors can serve two purposes, diagnostic (to in-point the problem) and prognostic (to make plans to solve a problem).In addition, he said that it is diagnostic 
because it can tell us the learner's grasp of a language at any given point during the learning process. It is also prognostic because it can tell the teacher to modify learning materials to meet the learners' problems.

Sercombe (2000) insisted that EA is of three purposes: Firstly, it can be used in finding out the level of language proficiency the learner reached. Secondly, it can be used in obtaining information about common difficulties in language learning, and thirdly, it can be used in finding out how people learn a language.

Candling (2001) considered EA as "the monitoring and analysis of learner's language". He added that the L2 learner's errors are potentially important for the understanding of the processes of second language learning . Olasehinde (2002) explained that it is inevitable that learners make errors and that errors are unavoidable and necessary in the process of learning. Mitchell and Myles (2004) showed that errors studying can reveal a developing system of the students L2 language.

Ferris (2002) showed that error analysis and corrective techniques can help in effective learning and teaching of English because foreign language is a gradual process, during which mistakes are to be expected in all levels of learning. He added that mistakes will not disappear simply because they have been pointed out to the learner, contrary to what some language learners and teachers believe. In fact, he insisted that mistakes is a natural process of learning and must be considered as part of cognition. So errors must be viewed positively.

Vahdatinejad (2008) mentioned that error analyses are fruitful in determining what a learner needs to be taught because it provides the necessary information about what is lacking in the linguistic competence. He made distinction between errors and lapses .In fact ,he sees that lapses are produced even by native speakers, and can be corrected by themselves.

In the view of the stated value of errors and error analysis, the researcher uses it to find out the written English errors of tenth grad students schools of Ajloun. hopping to offer solutions to avoid those errors because he thinks that it is very important for teachers to show their students how to deal with writing and how to master it by analyzing the errors they commit in their writing.

\section{Statement of the problem}

Large number of Arabic - speaking learners of English as well as learners of English from different language backgrounds may face a great amount of difficulty in learning English therefore there has been a kind of constant interest in conducting studies in second and foreign language leaning which investigate the errors made by the learners and suggesting plausible interpretations. All over the last decades, These studies focused on learner's errors and analyzing them.

Vahdatinejad (2008) found that students committed errors in tenses, word choices and prepositions. Tenth grade students in Ajloun are not an exception. They commit serious errors in their composition and teachers of English should pay more attention to these errors. This study was an attempt to investigate the grammatical and the lexical errors committed in the written English by male and the female tenth grade students in Ajloun. Also, this study was an attempt to give plausible explanations to the causes of these errors. The areas of grammatical errors are morphology, function words, articles, syntax, word order and tense errors. The areas 
of lexical errors are: lexical items wrongly used in place of others, wrong collections wrongly used in sentences, exotic meanings used in lexical items.

The researcher thinks that this study gains its importance of being different because many of the studies shed the light on one area of errors; one studied the errors of grammars, one studied the errors of syntax and one studied the errors of morphology, but none of them studied the errors of lexical meanings. on the contrary, this study comes to shed the light on all of areas of errors, errors of grammar, errors syntax, error of morphology, errors of words order and errors of lexical meanings . In addition, it is the first study of errors of essays committed by the tenth grade students in schools of Ajloun.

\section{Purpose of the study}

This study aims to achieve the following:

1.Identifying the written errors of English committed by the tenth grade students in schools of Ajloun.

2.estimating the predominant errors and the least ones.

3.explaining the causes of the written errors of English committed by the tenth grade students in schools of Ajloun.

4.providing suggestions for further research.

5.providing suggestions, recommendation and guidelines to help the students to avoid the errors.

\section{Questions of the study}

This study aims to answer the following questions: -

1. How widespread are grammatical and lexical errors in the essays of tenth grade students in Ajloun?

2. What are the predominant errors in the essays of the tenth grade students in Ajloun?

3. What are the least errors in the essays of the tenth grade students in Ajloun?

4. What are the causes and sources of the errors?

5. What recommendations can be suggested to help students write without committing serious errors while writing essays?

\section{Review of related literature}

"The answers you get from literature depend on the questions you pose".

\section{Margaret Atwood}

It is important to shed the light on some of the studies conducted on student's errors all around the world. The researcher was selective in reviewing the related literature conducted about errors analysis concentrating on those which are useful in taking advantage of the procedure and ways of account.

Ahmad (1986) studied secondary school students' errors in formulating wh-questions. He aimed to describe, analyze and explain the secondary cycle students' errors in formulating wh- questions. These errors were: word order, verbal form, wh - question word, auxiliary replacement, redundancy, repetition of the underlined words, and irrelevant question. The errors were identified, classified and the occurrences of errors in each type were counted. 
The sample consisted of 150 students who were randomly selected from two secondary schools chosen from all the secondary in Beit RAS office of education. The study raised the following questions: First, are there any significant difference in the occurrences of the eight types of errors in formulating wh- questions taken together, due to the grade of the students? Second, which types account for the differences among the three grades?

Third, are there any significant differences in the occurrences of the eight types of errors in formulating wh - questions taken together, due to sex of the students? And fourth, which types account for the differences between six ?

The results of the study showed that there were significant difference between males and females on the eight dependent variables taken together, there were significant differences among grades on the eight dependent variables taken together, females committed more errors in repetition of the underlined word, irrelevant questions and verbal form.

Simbwa (1987) investigated the causes of syntactic errors in the English essays of Uganda - speaking male and female public secondary students from Kampala - Entebbe area Uganda. The sample of the study consisted of 94 males and 14 females students of the academic year 1985, chosen randomly from four schools which were randomly selected from the 16 public secondary schools in the above area. The Independent variables of the study were the students grade and their sex while the dependent variables were the following types of syntactic errors: First, noun phrase errors. Second, verb phrase errors. Third, sentence structure errors. Fourth, Word-order errors And fifth, transformation errors. The results of the study showed that The predominant errors among male students in both grades were prepositions, pronouns and tense, the most predominant error type for females in both grades was prepositions.

Al-Hassan (1989) conducted a study about the errors committed by Jordanian secondary male students in their learning of English passive constructions. The sample was 30 first, 30 second and 30 third a academic secondary male students. It was selected randomly from five academic secondary government schools in the city of Irbid. The hypothesis of the study was that there would be statistically significant differences among the three levels of students with respect to the simple past, simple present, past prefect future and the models of passive voice. The analysis of the study revealed that there were no statistically significant differences among the three levels of students with respect to the errors made in past perfect, present perfect, simple future and the models of passive voice. The researcher insisted that the errors made by the three levels of students to the following possible sources: First, mother tongue interference. Second, performance. Third, ignorance of the grammatical rules of the target language and fourth overgeneralization and global and level errors.

Al-kahtybeh (1992) did his best to analyze the syntactic errors in the essays of Jordanian tenth grade students. The sample of the study consisted from 243 male and female students selected from 8 schools in Irbid district. The variables of the study were sex and grade. The study answered the following two questions:(a)-What types of syntactic errors are predominant in the essays of tenth grade students? (b)-are there and significant difference in the occurrence of the types of syntactic error due to their sex?

The results of the study showed that the predominant errors among male students were tense, auxiliary verbs and prepositions while the least predominant were pronouns and concord. The 
most predominant error type for females were tense, article and prepositions while the least predominant were subject - verb agreement and concord. The researcher attributed Various syntactic errors to: mother tongue interference, overgeneralization and ignorance of rules of usage. The researcher ended his study ended with group of recommendations such as : (a)-Teachers of English should motivate their students to write and the teachers themselves should take the matter seriously. (b)-It is necessary to hold an evaluation study on the tenth curriculum to reveal its efficiency and appropriateness to students' needs and interests.

Hazaymeh (1996) made a study that aimed at investigating the second secondary students' errors in learning English verb tenses. The sample was of 587 students from public schools and 172 students from private schools. Both male and female students in scientific and literary streams were involved in this study. Analysis of variance was used in analyzing the data of the study. Then means for each variable were found in order to answer the questions of the study. The researcher attributed the errors made by the students to group of reasons such as (a)- mother lounge interference, (b)-overgeneralization, (c)-the complexity of the structures of the English verb tenses, (d)- a strategy of parallel structure and (c)- the ignorance of grammatical rules.

Al-bakri, (1998) conducted study entitled "Error analysis of spelling mistakes committed by English majors at Yarmouk University". The study aimed at: (a)-investigating and analyzing the misspelling of 700 common words observed in the writings of the third - year Jordanian students at Yarmouk University. (b)-identifying the sources of the spelling errors made by the same students and (c)finding out if the spelling errors were different from male to female students. The sample of the study consisted of 200 students. 80 male students and 120 female students in the academic year 1996/1997. The researcher raised the questions: how widespread are spelling errors?, is error concentrated in particular categories?, do advanced learners differ markedly as to the distribution of their errors over various categories?, are there significant differences between male and female students in spelling errors?, are there words that are especially difficult to learn?

In this study, three processes of data analyzing were undertaken: (a)-identification of errors,(b)- categorization and (c)-explanation of these errors. The results of the study showed that: spelling errors are widely spread among advanced learners of English, error is highly concentrated in specific categories including substitution, inversion, omission and insertion, the advanced learners differ markedly as to the distribution of their error over various categories, there are significant differences between male and female students in spelling errors.

Cheng feng, (2000) wrote a paper describing anew- component called writing error analysis model (WEAM) in the coca system for instructing composition of writing in Japanese as a foreign language. He explained that it can be used for: (a)- analyzing learners' writing error in certain types of morphological error

and (b)- selecting the appropriate essays for learners' revising exercises.

Chanquoy (2001) conducted a research on "How to make it easier for children to revise their writing" to examine if a delay between writing and revising could improve the frequency and the nature of revisions. In two out of three writing sessions, the revising period was delayed to lighten the cognitive load associated with the revising process. Sixty children 
from 3rd to 5th grades participated in the study. In the study, Four types of errors have been distinguished:

(1)-Spelling errors, that concerned errors in words.

(2)-Grammar errors, that concerned gender and number, agreement of nouns, verbs and adjectives.

(3)-Script errors, that were errors of writing.

(4)-Punctuation errors, that consisted in a lock or error of capital letters or of any punctuation make in the text.

The results showed that 3rd graders produces shorter texts, containing more errors, but revised more than 4th and 5th grader. In 3rd grader, text and grammatical errors were the most frequent type of formal error Spelling, script errors had similar percentages and punctuation errors were the rarest type of error. Grammar errors were the most common type in 4th graders.

In conclusion, the researcher found that this brief review of related literature of great value and important to this study. In fact, it guided him in the process of: (1)-shedding the light on the importance of studying and analyzing errors of the written English. (b)- determining the procedures of conducting the study and (c)-providing him with insights to explain the source of the committed errors in the essays of the students of Ajloun schools.

\section{Methodology}

\section{Population of the study}

The population of the study consisted of all tenth grade students in Ajloun, Jordan. The number of students is (3321). (1600) Students are females and (1721) students are males. All of them study in Ajloun schools for the second semester of the academic year 2011/ 2012.

\section{The Sample:}

The researcher found that 63 schools have tenth grade students in Ajloun.34 are for females while the other 29 schools are for males. The sample consisted of 350 students selected randomly from students from group of Ajloun schools and that guarantees the representation of the defined students in the population.

\section{Data Collection:}

The study aimed at analyzing the errors of the Written Production of English Essays of Tenth Grade Students in Ajloun Schools, Jordan. Therefore, the data collected from the essays, which were written by some of them by using random samples. The students who were selected randomly were asked to write an essay about "A journey to the ancient city of Jerash, Jordan" in a free composition exercise in an ordinary class of English. Then the papers of the essays were collected.

\section{Data Analysis}

Analyzing the data depended on a table of errors was adopted from a Ph.D. thesis of ( Wakkad,1980). The table shows two kind of errors:

1- Grammatical errors: they include five areas:-

A- morphology: there are eleven types of errors: - 


\section{Macrothink}

Omission of " s" singular.

Addition of suffers to infinitive.

Lack of agreement between subject and verb.

Lack of agreement between nouns and pronouns.

Demonstratives.

Agreement between numbers.

Irregular verbs.

Model auxiliaries occurred with simple past.

Inappropriate plural ending.

Using other parts of speech than objectives.

Omission of relative pronouns.

B- function words: they include:

1.prepostions: there are three types of errors:

A-confusion.

B-omission.

C-Insertion.

2.articles: there are three types of errors:-

A- addition of " the "

B- omission of "a"

C- addition of "a"

C- syntactic errors there are seven types of errors : -

A- sequence of tense

B-errors in using progressive.

C-omission of verb to be.

D. omission of the main.

E. omission of to.

F. addition of to.

G. passive voices.

D- Word order: errors associated with nouns , two nouns , one of which is used attributively.

E-Tense errors: there are three types of errors:

Present instead of past.

Past instead if present.

Confusion of tenses.

lexical errors: there are three types: -

A-lexical items wrongly used in place of others.

B-wrong collections wrongly used in the scripts.

C-exotic meanings used in lexical items.

\section{Explanation of errors:}

Explanation of errors is considered one of the main important goals of errors analysis, so serious hard attempt was made to explain the plausible cause of the students' errors. They could be attributed to many source: mother tongue interference, intralingual 
interference, teachers, false analogy and the familiarity of the appropriate collections. Analyzing the collected data will indicate the sources of these errors.

\section{Results and discussion of results.}

The results are presented under the following headings:

1. Number of errors of each type: function words, morphology, syntax, tenses, wordsorder and lexical.

2. Hierarchical typologies of errors according to the main categories.

3. Hierarchical typologies of errors within each category.

4. Total number of errors.

5. Explanation of the sources of errors.

The researcher presented Each category in a table which shows the number of errors, examples of these errors and the possible causes of these errors.

\section{Discussion of results}

Table (1)

Frequencies of errors of prepositions

\begin{tabular}{|l|l|l|l||}
\hline Type of error & $\begin{array}{l}\text { Number of } \\
\text { errors }\end{array}$ & Examples & Causes \\
\hline Confusion & 48 & $\begin{array}{l}\text { I went to jerash on 2008. } \\
\text { I work up in 8 'oclock }\end{array}$ & $\begin{array}{l}\text { Intralingual } \\
\text { interference. } \\
\text { Arabic interference }\end{array}$ \\
\hline Confusion & 36 & $\begin{array}{l}\text { We went jerash } \\
\text { Jerash is located in - middle of Jordan. }\end{array}$ & Arabic interference. \\
\hline Insertion & 86 & $\begin{array}{l}\text { I talked with my father. } \\
\text { In the last year, we went to jearsh. }\end{array}$ & Arabic interference \\
\hline $\begin{array}{l}\text { Total number of } \\
\text { errors }\end{array}$ & 170 & & \\
\hline
\end{tabular}

Table (1) indicates that the total number of prepositions is " 170 " these errors could be attributed to two sources : mother tongue interference which is the Arabic language, and intralingual interference, intralingual errors " reflect the general character of the learning such as faulty overgeneralization, incomplete application of rules and failure to learn conditions under which rules apply " ( dulay ,1982). A good example which reflects Arabic interference in learning the English language as presented in the writings of the students a sentence like " in the last year, we went to jearsh". In this example, the students wrongly used the preposition " in " where they should not use it because it is a literal translation to what it is said in Arabic " filsanehel-el-medieh ". An example of intralingual errors is a sentence like " I went to jerash on 2008." It can be noticed that in this example, the preposition " on " is used wrongly instead of the preposition " in ". This kind of error can not attributed to the mother tongue since the same preposition is used in both languages. This type of error could be attributed to intralinagual. Interference in the sense that students may be overgeneralizing the use of the preposition " on " to areas where they should not be used.

Table (2) 
Number of errors committed by students concerning: addition of " the ", addition of " a " and omission of " a ".

\begin{tabular}{|l|l|l|l||}
\hline Type of error & Number of errors & Examples & Causes \\
\hline Addition of " the" & 36 & $\begin{array}{l}\text { We went home at the } \\
\text { night. } \\
\text { It comes after the } \\
\text { jerash. }\end{array}$ & $\begin{array}{l}\text { Arabic interference. } \\
\text { Over generalizaiotn }\end{array}$ \\
\hline Addition of "a" & 15 & $\begin{array}{l}\text { It a very beautiful } \\
\text { city. } \\
\text { We saw a many } \\
\text { people. }\end{array}$ & $\begin{array}{l}\text { Intralingual mainly } \\
\text { overgeneralization }\end{array}$ \\
\hline Omission of " a " & 8 & $\begin{array}{l}\text { I asked - teacher from } \\
\text { my school about } \\
\text { jrash. } \\
\text { I am - student in 10th } \\
\text { grade }\end{array}$ & Arabic interference \\
\hline $\begin{array}{l}\text { Total number of } \\
\text { errors }\end{array}$ & 59 & & \\
\hline
\end{tabular}

As the table shows the total number of errors of articles is "59" of which "36" errors concerning addition of " the ", "15" errors concerning addition of " a " and "8" errors concerning omission of " a " these types could be attributed to either Arabic interference or oregeneralization. Addition of " the" and omission of " a" could be attributed mainly to interference form the mother tongue. That is to say, there is a tendency in the Arabic language to use the definite article with nouns, that is why we see students learning English exhibit such a phenomenon in their writing and producing sentence like " we went home at the night" it can be noticed from this sentence that the definite article is used with the word night where it should not be used and this reflects the structure of the Arabic language.

As far as the omission of " a " is concerned, this can be attributed to the fact that the Arabic language does not have this article, so the students avoid using it in most sentences where it should be used. Because of that we can say that the main reason for the omission of "a" is mother tongue interference. An example, which shows that, is the following: - I asked teacher from my school about jerash.

Table (3)

Number of errors of morphology, examples about them and their causes.

\begin{tabular}{||l|l|l|l||}
\hline Type of error & $\begin{array}{l}\text { Number } \\
\text { of errors }\end{array}$ & Examples & Causes \\
\hline $\begin{array}{l}\text { Omission of "s" } \\
\text { singular }\end{array}$ & 10 & $\begin{array}{l}\text { My friend get up as seven } \\
\text { He go from Ajloun to jerash. }\end{array}$ & $\begin{array}{l}\text { Mother tongue learning } \\
\text { strategy. }\end{array}$ \\
\hline $\begin{array}{l}\text { Addition of } \\
\text { suffixes infinite }\end{array}$ & 1 & We can wants & $\begin{array}{l}\text { Overgeneralization } \\
\text { incomplete knowledge of the } \\
\text { rule }\end{array}$ \\
\hline
\end{tabular}




\begin{tabular}{|c|c|c|c|}
\hline $\begin{array}{l}\text { Lake of agreement } \\
\text { between stv. }\end{array}$ & 104 & $\begin{array}{l}\text { We was in the road. } \\
\text { It exist } 70 \mathrm{~km} \text { to the north of Ajloun }\end{array}$ & Arabic interference \\
\hline $\begin{array}{l}\text { Lack of agreement } \\
\text { between nouns and } \\
\text { pronouns }\end{array}$ & 3 & $\begin{array}{l}\text { My family was worried a bout his } \\
\text { friend. }\end{array}$ & $\begin{array}{l}\text { Arabic interference } \\
\text { incomplete knowledge of the } \\
\text { rules. }\end{array}$ \\
\hline Demonstratives & 11 & $\begin{array}{l}\text { The romans built this high buildings. } \\
\text { These tree are on the hill }\end{array}$ & Arabic interference. \\
\hline $\begin{array}{l}\text { Agreement } \\
\text { between number }\end{array}$ & 18 & $\begin{array}{l}\text { Two of my friend came to visit } \\
\text { jerash. } \\
\text { I visited jerash before two month }\end{array}$ & Arabic interference. \\
\hline Irregular verbs & 27 & $\begin{array}{l}\text { The romans builded jerash. } \\
\text { They taked photos in jerash. }\end{array}$ & Overgeneralization \\
\hline $\begin{array}{l}\text { Modal allxiliories } \\
\text { occurred with } \\
\text { simple past. }\end{array}$ & 7 & $\begin{array}{l}\text { We can saw all things. } \\
\text { They would spoke about jerash. }\end{array}$ & $\begin{array}{l}\text { Incomplete knowledge of the } \\
\text { rule. }\end{array}$ \\
\hline $\begin{array}{l}\text { In appropriate } \\
\text { plural ending }\end{array}$ & 4 & $\begin{array}{l}\text { Many Jordanian visited jerash. } \\
\text { The polices helped us. }\end{array}$ & Arabic interference's. \\
\hline $\begin{array}{l}\text { Using other pasts of } \\
\text { speech than } \\
\text { adjectives }\end{array}$ & 3 & $\begin{array}{l}\text { I was very worry about the journey. } \\
\text { We were sleep at } 9 \text { o'clock. }\end{array}$ & $\begin{array}{l}\text { Incomplete knowledge of the } \\
\text { rules. }\end{array}$ \\
\hline $\begin{array}{l}\text { Omission of } \\
\text { relative pronouns. }\end{array}$ & 12 & $\begin{array}{l}\text { Jerash has a lot of buildings - tell us } \\
\text { about past. } \\
\text { Jerash is a place - people like very } \\
\text { much. }\end{array}$ & Arabic interference's. \\
\hline Total number & 200 & & \\
\hline
\end{tabular}

Table (3) shows that the total number of errors of morphology is (200) with variation among subcategories within this category. The most predominant type of errors within this category is errors of " lack of agreement between subject and verb." They are " 104" errors. Whereas the least type is the " addition of suffixes to infinitive ". in fact there is just one error. Examples of the former types are:-

1. we was in the road.

2. It exist $70 \mathrm{~km}$ to the north of Amman.

This type of errors can be attributed to overgeneralization where the students extend the rules because they don't have good knowledge about these rules so they use "was" with the subject "we " where they must use " were". Also, they use "it" as a subject in a simple present and they do not add "s" singular to the main verb where they must.

As it was mentioned above " addition of suffixes to infinitive " is the least type of errors of morphology. The only example written by the students is " we can wants". It is clear cut that Arabic interference is not the cause of such types of errors. Adding " s " to the infinitive after modals- such rule does not exist in the Arabic language. This type of error can be attributed to overgeneralization of linguistic rules within the target language the learner studying. students 
make this type of errors because they overgeneralization the use of " s" with third person singular with verbs after modals where this " s " should not be added .

The number of errors of irregular verbs is (27) which means that it comes after the most predominant one " the lack of agreement between subject and verb " the following examples show this type of errors:-

1- The Romans builded jerash.

2-They taked photos in jerash.

This kind of errors can be attributed to overgeneralization. students understand the regular past forms of verbs which end with " ed " and they over- generalize the rules to irregular verbs which they do not know their conjugations thus overgeneralization is the negative counterpoint of intraligual transfer.

Table (4)

Errors of syntax: sequence of tense, errors in using progressives, omission of verb to be, omission of the main verb, omission of to, addition of to and passive voice.

\begin{tabular}{||l|l|l|l||}
\hline Type of error & $\begin{array}{l}\text { Number of } \\
\text { errors }\end{array}$ & Examples & Causes \\
\hline Sequence of tense & 6 & $\begin{array}{l}\text { After i bought cakes, I go to the } \\
\text { teacher. } \\
\text { The talked and walk. }\end{array}$ & $\begin{array}{l}\text { Intralingual } \\
\text { interference. }\end{array}$ \\
\hline $\begin{array}{l}\text { Errors in using } \\
\text { progressive }\end{array}$ & 11 & $\begin{array}{l}\text { It never going to journey to } \\
\text { jerash. } \\
\text { I walking in jerash. }\end{array}$ & Incomplete knowledge \\
\hline Omission of verb "to be" & 3 & $\begin{array}{l}\text { It- a very long trip. } \\
\text { Thus food- for him. }\end{array}$ & Arabic interference \\
\hline $\begin{array}{l}\text { Omission of verb the } \\
\text { main verb }\end{array}$ & 90 & $\begin{array}{l}\text { The weather very nice. } \\
\text { I to jerash. } \\
\text { We went- see the old buildings. }\end{array}$ & $\begin{array}{l}\text { Incomplete knowledge } \\
\text { of the rules. }\end{array}$ \\
\hline Omission of "to " & 4 & $\begin{array}{l}\text { We phoned to my father. } \\
\text { We began to feel hungry. }\end{array}$ & Arabic interference. \\
\hline Addition of "to" & 54 & $\begin{array}{l}\text { Jerash considered to be } \\
\text { important. } \\
\text { It were built by the romans. }\end{array}$ & $\begin{array}{l}\text { Incomplete knowledge } \\
\text { of the rules. } \\
\text { Arabic interference. }\end{array}$ \\
\hline Passive voice & $\mathbf{1 2 7}$ & \\
\hline Total & 13 &
\end{tabular}

It is noticed that " omission of the main verb " is the greatest number of error within syntax category. Students tend to produce sentences (90 errors).

1- The weather - very nice.

2-I to jerash

The source of such type of errors is obvious interference from mother tongue. It is possible in Arabic to have sentences without verbs and they are called "nominal sentences", but in English this does not exist. For this reason students produce sentence without main verb 
reflecting the influence of their mother - tongue on the production of target language sentences:

Another type of errors is the sequence of tenses, the number of these errors is "6". Examples of this type are:

1- after I bought cakes, I go to the there.

2- they talked and walk.

In the examples mentioned above. The sentences begin with simple past but followed by verb in the simple present. This is an error because students should use past form instead of the present one. Which shows that the students have not captured the sequence rule of tenses. This type of error can be attributed to intralingual interference mainly incomplete knowledge of the rules.

One of the errors which we should draw our attention as teachers is the error of using passive voice. Examples of these errors would be: -

1.jerash considered to be important.

2. It were built by the Romans.

This kind of errors is attributed to the mother tongue interference and intralingual interference, the first example is a direct Arabic translation, the student did not use the right verb to be ( am , is, are, was, were ) when he had to.

In the second example, the error is attributed to the incomplete knowledge of rules. Simply, the student used " were" instead of " was " because he can not know when to use each one. Similarly for other types of errors within this category: omission of "the' and using progressive.

Table (5)

Number of errors of word order.

\begin{tabular}{||l|l|l|l||}
\hline Type of error & $\begin{array}{l}\text { Number of } \\
\text { errors }\end{array}$ & Examples & Causes \\
\hline $\begin{array}{l}\text { Errors associated with nouns: } \\
\text { Two nouns, one of which is } \\
\text { used attributively }\end{array}$ & $\begin{array}{l}\text { We prefer to come by August } \\
\text { because it is holiday summer. } \\
\text { Some stranger students were } \\
\text { there. }\end{array}$ & $\begin{array}{l}\text { Arabic interference } \\
\text { overgeneralization }\end{array}$ \\
\hline
\end{tabular}

About the errors of word order, they are not many - in fact, they are " 3" ones. they are attributed to overgeneralization and Arabic interference. Examples of there: 1.we prefer to come by august because it is holiday summer.

2.some strangers students were there

The students use nouns attributively where they should not be used. This can be attributed to overgeneralization because there are cases in English where nouns can be used attributively. But this not always right. Another cause could be Arabic interference as in the expression holiday summer instead of summer holiday.

Table (6)

Errors concerning tenses.

\begin{tabular}{|c|c|c|c|}
\hline Type of error & Number of errors & Examples & Causes \\
\hline
\end{tabular}




\begin{tabular}{|l|l|l|l||}
\hline $\begin{array}{l}\text { Present instead of } \\
\text { past }\end{array}$ & 191 & $\begin{array}{l}\text { Yesterday, I visit jerash. } \\
\text { I did my best and take these } \\
\text { bags. }\end{array}$ & $\begin{array}{l}\text { Intralingual } \\
\text { interference. } \\
\text { Arabic interference }\end{array}$ \\
\hline $\begin{array}{l}\text { Past instead of } \\
\text { present }\end{array}$ & 5 & $\begin{array}{l}\text { We went everyday to jerash. } \\
\text { We come to the festival before } \\
\text { it began. }\end{array}$ & Arabic inferences. \\
\hline Confusion of tenses & 181 & $\begin{array}{l}\text { We saw the bus while we eat. } \\
\text { Ali gave among before we go. }\end{array}$ & $\begin{array}{l}\text { Arabic interference } \\
\text { Intralingual } \\
\text { interference. }\end{array}$ \\
\hline $\begin{array}{l}\text { Total number of } \\
\text { errors }\end{array}$ & 377 & & \\
\hline
\end{tabular}

The table above shows that there are three types of errors of tenses:-

1.present instead of past. Examples of this type could be:-

a- Yesterday, I visit jerash.

b-I did my best and take these bags.

2.past instead of present:-

a-We went everyday to jerash .

b-We come to the festival before it began.

3. Confusion of tenses:-

Examples of this kind :

a-We saw the bus while we eat.

b-Ali gave me the money before we are going.

These examples of errors show - taht they could be attributed to the mother tongue interference and incomplete knowledge of the rules, confusion of tenses is a result of intralingual factor stemming from the target language itself. This means that the students have not mastered when and how to use each tense and this shows why they are confused when they use such tenses.

Table (7)

Errors concerning lexical

\begin{tabular}{||l|l|l|l||}
\hline Type of error & $\begin{array}{l}\text { Number of } \\
\text { errors }\end{array}$ & Examples & Causes \\
\hline $\begin{array}{l}\text { Lexical items wrongly } \\
\text { used in place of others }\end{array}$ & 126 & $\begin{array}{l}\text { Their are very nice streets. } \\
\text { Jerash is a place were you enjoy } \\
\text { your time. }\end{array}$ & $\begin{array}{l}\text { Arabic interference } \\
\text { false analogy. } \\
\text { Overgeneralization. }\end{array}$ \\
\hline $\begin{array}{l}\text { Wrong collections wrongly } \\
\text { used in the essays }\end{array}$ & 47 & $\begin{array}{l}\text { They made there high joy time. } \\
\text { They made me felt good. }\end{array}$ & $\begin{array}{l}\text { Arabic interference } \\
\text { Overgeneralization. }\end{array}$ \\
\hline $\begin{array}{l}\text { Exotic meanings } \\
\text { Used in lexical items. }\end{array}$ & 67 & $\begin{array}{l}\text { I promotion everyone to visit it. } \\
\text { I know to an American man. }\end{array}$ & $\begin{array}{l}\text { False } \\
\text { Analogy }\end{array}$ \\
\hline Total number of errors & 240 & & \\
\hline
\end{tabular}


Table (7) shows that there are three types of lexical errors. In fact, there are "240" errors "126" errors are lexical items wrongly used in place. "47" errors are wrong collections wrongly used in the essays and "67" errors are exotic meanings used in lexical items.

Examples of the first type could be :

a- Their are many beautiful streets.

b- Jerash is a place were you enjoy your time.

Examples of the second type could be :

a- They made their high joy time.

b-They make me felt good.

Example of the third type could be:

a- I promotion everyone to visit it.

b- I knew to an American man.

All of these types of lexical errors are attributed to many sources of errors.

Arabic interference: one lexical in Arabic corresponds to more than one lexical item in English.

Mutual interference between lexical items which are similar phonetically.

Literal translation of Arabic expressions.

The cultural differences between Arabic and English.

Analogy.

Table (8)

Hierarchy of errors within morphology category

\begin{tabular}{|c|c|c|c|}
\hline Area & No & Type of error & $\begin{array}{l}\text { Number of } \\
\text { errors }\end{array}$ \\
\hline \multirow{11}{*}{ 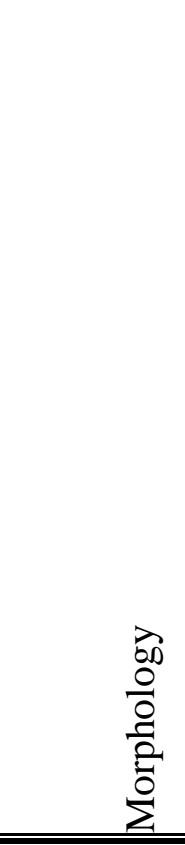 } & 01 & $\begin{array}{l}\text { Lack of agreement between } \mathrm{s}+ \\
\mathrm{V}\end{array}$ & 104 \\
\hline & 02 & Irregular verbs & 27 \\
\hline & 03 & Agreement between numbers & 18 \\
\hline & 04 & Omission of relative pronouns & 12 \\
\hline & 05 & Demonstratives & 11 \\
\hline & 06 & Omission of "s" singular & 10 \\
\hline & 07 & $\begin{array}{l}\text { Modal auxiliaries accrued with } \\
\text { simple past. }\end{array}$ & 7 \\
\hline & 08 & Inappropriate plural ending. & 4 \\
\hline & 09 & $\begin{array}{l}\text { Lack of agreement between } \\
\text { nouns and prounes. }\end{array}$ & 3 \\
\hline & 10 & $\begin{array}{l}\text { Using other parts of speech than } \\
\text { adjectives. }\end{array}$ & 3 \\
\hline & 11 & Addition of suffixes infinitive & 1 \\
\hline
\end{tabular}

Table (9)

Hierarchy of errors of function words. 


\begin{tabular}{||l|l|l|}
\hline \hline No & area & Number of errors \\
\hline 01 & Insertion of prepositions & 86 \\
\hline 02 & Confusion of prepositions & 48 \\
\hline 03 & Addition of " the " & 36 \\
\hline 04 & Omission of prepositions & 36 \\
\hline 05 & Addition of "a" & 15 \\
\hline 06 & Omission of "a" & 8 \\
\hline \multicolumn{2}{|l|}{ Total number of errors } & 229 \\
\hline
\end{tabular}

Table (10)

Hierarchy of errors of syntax.

\begin{tabular}{||l|l|l|l||}
\hline \hline \multirow{4}{*}{ Area } & No & Type of error & Number of errors \\
\hline & 01 & Omission of the main verbs & 90 \\
\cline { 2 - 5 } & 02 & Passive voics & 54 \\
\cline { 2 - 5 } & 03 & Addition of " to " & 13 \\
\cline { 2 - 4 } & 04 & Errors in using progressive & 11 \\
\cline { 2 - 4 } & 05 & Sequence of tenses & 6 \\
\cline { 2 - 4 } & 06 & Omission of " to " & 4 \\
\cline { 2 - 4 } & 07 & Omission of verb to be & 3 \\
\hline \multirow{6}{*}{ Total numbers of errors } &
\end{tabular}

Table (11)

Hierarchy of errors of tenses

\begin{tabular}{||l|l|l||}
\hline No & area & Number of errors \\
\hline 01 & Presented in steed of past & 191 \\
\hline 02 & Confusion of tenses & 181 \\
\hline 03 & Past in steed of present & 5 \\
\hline Total number of errors & 377 \\
\hline
\end{tabular}

Table (12)

Hierarchy of grammatical errors

\begin{tabular}{|l|l|l||}
\hline No & area & Number of errors \\
\hline 01 & Tenses & 377 \\
\hline 02 & Function words & 229 \\
\hline 03 & Morphology & 200 \\
\hline 04 & Syntax & 127 \\
\hline 05 & Word order & 3 \\
\hline Total number of errors & 936 \\
\hline
\end{tabular}


Table (13)

Hierarchy of lexical errors.

\begin{tabular}{|l|l|l|}
\hline No & area & Number of errors \\
\hline 01 & Lexical items wrongly used in place of other & 126 \\
\hline 02 & Exotic meanings used in lexical items & 67 \\
\hline 03 & Wrong collection wrongly used in the essays & 47 \\
\hline \multicolumn{2}{|l|}{ Total number of errors } & 240 \\
\hline
\end{tabular}

\section{Conclusion}

It can be concluded that first, the most predominant errors among tenth grad students in Ajloun schools within morphology were errors of lack between subject and main verb and the learnt ones were the addition of suffixes to infinitive. second, the most predominant errors among tenth grade students in Ajloun schools within function words were errors of insertion of prepositions and the least ones were the omission of "a" .third, the most predominant errors among tenth grade students in Ajloun schools within syntax were errors of omission of the main verb and the least ones were the omission of verb to be. forth, the most predominant errors among tenth grade students in Ajloun schools within tenses were errors of using present instead of past and the least ones were using past instead of present. fifth, the most predominant errors among tenth grade students in Ajloun schools within lexical items were errors of lexical items wrongly used in place of others and the least ones were wrong collections wrongly used in the essays. sixth, Errors were attributed to main sources :

a- Arabic interference and b- interalingual interference.

\section{Implications for teachers}

In the light of the results of the study, group of pedagogical implications can be presented: first,in the view of the predominance of lack between subject and main verb errors, prepositions errors, omission of the main verb errors and using present instead of past errors. It is suggested that language teacher pay attention to this problem . remedial measures could include increasing exercise that focus on these subjects. second, teachers should adopt approaches to writing and specific activities that can make writing easier and more enjoyable for both learners and teachers. third, wherever teaching certain grammatical rules, teachers should provide their students with these limitations or restrictions of these rules and teach them how to use in a variety of meaningful contexts. fourth, it is important for teachers to realize that errors are a natural and important part of the learning process itself, and not all of them come from mother tongue interference. fifth, mother tongue interference and ingtralingual interference are the main sources of errors of written English of tenth grade students of Ajloun schools.

\section{Recommendations:}

In the light of the results of the study, the researcher recommends the following: first, A research on the methods of teaching English composition can be carried out to see if there is a relationship between errors committed by students and these methods. second, it is valuable to find out the effect of error correction strategy or students' errors. Third, finding out remedial programs to help students avoid committing errors and make sure of the effect of 
these programs experimentally. Fourth, to determine whether there is a significant relationship between the experience and qualifications of teachers on the one hand and students' grammatical and lexical errors. Fifth, conducting studies on the extent of Arabic intrusion in the learning of written English of different stages.

\section{References :}

Abdel-ghani, M.A.(1989).An analysis of errors made by Jordanian secondary male students in their learning of English passive constructions - unpublished master's thesis, yarmouk university, Irbid, Jordan.

Abuniaj, U. A. (1992). a longitudinal and cross-lexical errors of Syrian university English essays.1992 unpublished master's thesis . University of Damascus.

Al-bakri, L. M. (1998). Error analysis of spelling mistakes committed by English majors at Yarmouk University. Unpablish master's thesis. Yarmouk university, Irbid, Jordan.

Al-khatatybeh, M. (1992). An analysis of syntactic errors in the essays of Jordanian tenth grade students. Unpublished master's thesis, Yarmouk University. Irbid, jordan.

Atwood, M. (n.d.). Retrieved January 27, 2012, from

www.brainyquote.com/quotes/quotes/m/margaretat $383862 . h t m$

Brown, C. (2000). The interrelation between speech perception and phonological acquisition from infant to adult. Great Britain: Blackwell Publishers Limited.

Hazaymeh, Y. A. (1996) . An analysis of the errors made by Jordanian second secondary students in learning English verb tenses. Unpublished master's thesis, Yarmouk University, Irbid, Jordan.

Candling, R. B. (2001). Vocabulary and language teaching. New York: Longman Inc.

Chang feng, H.O.(2000) . Mark-up-based writing errors analysis model in an on - line classroom. Eric.www.Eric.com.

Chanquoy, L. (2001). How to make it easier for children to revise their writing. British journal of educational psychology printed in great Britain.

Corder, S. P. (1967). The significance of learners' errors. International Review of Applied Linguistics, 5(4), 161-169.

Ferris, D. (2002). Treatment of error in second language student writing. Ann Arbor: University of Michigan Press.

Dryden, J. ( n.d). Retrieved February 29,2012,from http://www.aboutfreelancewriting.com/2009/07/errors-quotes-to-inspire-writers

Mitchell, R. and Myles, M. (2004). Second language learning theories. New York: Hodder Arnold.

Olasehinde, M. O. (2002). Error analysis and remedial pedagogy. In Babatunde S. T. and D. Raimes, A. (1983).Techniques in teaching writing. New York: Oxford University Press.

S.Adeyanju (eds.). Language, meaning and society. Ilorin: Itaytee Press and Publishing Co., Nigeria. 
Sercombe, P. G. (2000). Learner language and the consideration of idiosyncracies by students of English as a second or foreign language in the context of Brunei Darulsalam. In A.M. Noor et al. (eds.) Strategising teaching and learning in the 21st century. Proceedings of the European Journal of Social Sciences - Volume 8, Number 3 (2009) Vahdatinejad, S. (2008). Students' error analysis and attitude towards teacher feedback using a selected software: a case study. Unpublished Master's thesis. University Kebangsaan, Malaysia, Bangi

Wakkad, M. (1980). Arabic intrusion in the learning of written English in Egyptian preparatory schools. Unpublished Ph.D. Dissertation, University Coll., Cardiff, United Kingdom.

\section{Appendix A}

Instrument of analysis

Grammatical errors

(Wakkad,1985)

\begin{tabular}{|c|c|c|}
\hline Area & Types & Number of errors \\
\hline $\begin{array}{l}\text { Function } \\
\text { words }\end{array}$ & $\begin{array}{l}\text { Prepositions } \\
\text { Confusion } \\
\text { Omission } \\
\text { Insertion } \\
\text { Articles } \\
\text { Addition of " the " } \\
\text { Addition of " a " } \\
\text { Omission of " a" }\end{array}$ & \\
\hline $\begin{array}{l}\overrightarrow{b 0} \\
0 \\
0 \\
0 \\
0 \\
\stackrel{0}{0} \\
\stackrel{0}{2}\end{array}$ & $\begin{array}{l}\text { Omission of " } \mathrm{s} \text { " singular } \\
\text { Addition of suffixes to infinitive } \\
\text { Lack of agreement between } \mathrm{s}+\mathrm{v} \\
\text { Lack of agreement between nouns and } \\
\text { prounous } \\
\text { Demonstratives } \\
\text { Agreement between numbers } \\
\text { Irregular verbs } \\
\text { Model auxiliaries occurred with simple past } \\
\text { inappropriate plural ending } \\
\text { Using other parts of speech than adjectives } \\
\text {.Omission of relative pronon. }\end{array}$ & \\
\hline
\end{tabular}




\begin{tabular}{|c|c|c|}
\hline 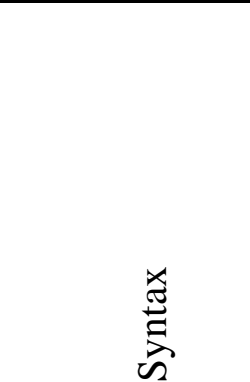 & $\begin{array}{l}\text { Sequence of tense } \\
\text { Using progressives } \\
\text { Omission of verb to be } \\
\text { Omission of the main verb } \\
\text { Omission of to } \\
\text { Addition of to } \\
\text { Passive voice }\end{array}$ & \\
\hline Word order & $\begin{array}{l}\text { Errors associated with nouns. ( two nouns } \\
\text { one of which is used attributively). }\end{array}$ & \\
\hline Tenses & $\begin{array}{l}\text { Present instead of the past. } \\
\text { simple past instead of simple present } \\
\text { confusion of tenses. }\end{array}$ & \\
\hline Area & Types & Number of errors \\
\hline Lexical errors & $\begin{array}{l}\text { Lexical items wrongly used in place of } \\
\text { others wrongly collection wrongly used in } \\
\text { the composition exotic meaning used in } \\
\text { lexical items. }\end{array}$ & \\
\hline
\end{tabular}

